\title{
THE ANALYSIS DEMAND FOR ANIMAL SOURCE FOOD IN INDONESIA: USING QUADRATIC ALMOST IDEAL DEMAND SYSTEM
}

\author{
Khoiriyah NIKMATUL ${ }^{1}{ }^{*}$, Anindita RATYA ${ }^{2}$, Hanani NUHFIL ${ }^{2}$, \\ Muhaimin Abdul WAHIB ${ }^{2}$ \\ ${ }^{1}$ Departement of Agribusinees, Faculty of Agriculture, University of Islam Malang, Malang, Indonesia \\ ${ }^{2}$ Faculty of Agriculture, University of Brawijaya, Malang, Indonesia
}

Received 23 June 2019; accepted 10 January 2020

\begin{abstract}
Indonesia has been experiencing rising animal source food prices during the last five years (decade). In this paper we explore how changes of animal source food prices impact on their demand Indonesia 2016 as expressed in income and price elasticities.

Take into account for changes in consumption patterns, as expressed in substitution and complement effects among food items, by including own and cross price elasticities obtained through the parameter estimation of a demand system using QUAIDS.

With respect to the total animal food expenditure, chicken meat, beef, fish and milk are luxury goods, while (only) egg is normal goods. The luxuriousness of chicken meat, beef, fish and milk powder decrease with increasing household income level as expressed in quintile level. The results also show that consumers substitute high value commodities such as chicken meat, beef, fishes and powdered milk in case of rising prices with the cheaper and lower preferences. Consequently, households consume a less diversified diet in times of high animal source food prices, focusing their diet on cheaper animal source food commodities. High value animal source foods play an important role in a diversified and nutritionally balanced diet, since they are rich in proteins and essential amino acid. Animal source food "inflation", which has been led by high value animal agricultural commodities, therefore threatens to worsen the nutritional status of the Indonesian consumer, especially the lower income level.
\end{abstract}

Keywords: animal source food, consumption-behavior, demand system, urban, rural.

JEL Classification: Q18, D11, Q11, Q18.

\section{Introduction}

The first goal of the Sustainable Development Goals (SDG) is without (zero) poverty (Robert, Parris, \& Leiserowitz, 2005). It means all households can meet the minimum basic needs of both food and non-food (Indonesian Bureau of Statistics, 2016). The pattern of household consumption is one of the most important indicators of a country's economic development. Changes in consumption patterns are influenced by prices and income (Pangaribowo, 2010). As a developing country, the Indonesian largest household expenditure is for food, about $55.83 \%$ in rural areas and $44.17 \%$ in urban areas and mostly for staple food. Expenditures for animal source food groups were quite low. Based on quantile expenditure from the lowest to the highest quintile, the expenditure share of animal source foods were $16.67 \%, 22.48 \%, 23.53 \%, 26.31 \%$, and $30.23 \%$ for the lowest quintile (Q1) to highest quintile (Q5) respectively (Susenas, 2016). The impact of protein deficiency in children can be sedentary, such as intelligence and stunting. Animal food as a source of protein is an important food that must be consumed by households (Akaichi \& Revoredo-Giha, 2014; Cockx, Francken, \& Pieters, 2015). The lack of protein consumption is exacerbated by rising prices of animal protein source foods. There is a tendency for increasing animal protein food prices in the last five years. The price of beef in 2011 was Rp. 65,900 while in 2016 amounted to Rp. 106,600 (Nendissa et al., 2018).

Price increases cause changes in consumption patterns (Sadiyah, 2019), as well as household purchasing power decreases (Tefera, Demeke, \& Rashid, 2012; Bellemare, Barrett, \& Just, 2013). In Indonesia, there are many households that do not meet the Protein Recommended Dietary Allowances (RDA) of 57gram/capita/day. At national level,

*Corresponding author. E-mails: nikmatulkhoiriyah431@gmail.com;nikmatul@unisma.ac.id 
protein consumption per capita per day of households based on expenditure quintiles were $45.16,53.18,59.63$, 67.71 , and $80.48 \mathrm{~g}$ protein per day (Indonesian Bureau of Statistics, 2016). It means that the protein consumption at the two lowest quintiles (about 40\%) still below the RDA protein. Poor nutritional status still prominent in Indonesia, which is indicated by under-weight and under-height. Toddlers (infants and children aged less than five years) aged 0-23 months who grow abnormally short is $21.7 \%$ and this number increases by $27.5 \%$ for ages $0-59$ months (Kadir, 2015). The number of pregnant women who calories shortage is quite high about $44.1 \%$, and those lacking protein is $48.1 \%$ (Karima \& Achadi, 2012). Research on the pattern of food consumption has been carried out by Sa'diyah (2019).

There were several researches regarding the food demand system using the QUAIDS, such as (Pangaribowo, 2010) in Indonesia, (Elijah Obayelu, Okoruwa, \& Ajani, 2009) in Nigeria, (Mittal, 2010) in India, and (Korir, Rizov, \& Ruto, 2018) in Kenya. These previous studies discuss the impact of price changes on food demand. The parameter of QUAIDS use to estimate price and income elasticity, to show the substitution or complementary relationships between foods as well as income elasticities. These researches were only focused on rural-urban areas as analysis unit. In this study, the focus of data analysis is not only based on urban-rural but also on quintile of income as carried out by Ackah and Appleton (2007).

This research aims to analyze the impact of price change and income increases on the demand and consumption patterns of animal source food at various quintiles of income and settlement types in Indonesia. Through this analysis, we obtain income and price elasticities, both uncompensated and compensated. An important contribution of the paper is the combination of using extended QUAIDS methodology and sample covers all Indonesian's household. Compared to other demand systems, QUAIDS is more appropriate since it allows for non-linearity in the Engel curves which are commonly the case when analyzing aggregate commodity food demand system at household level.

Generally, in Indonesia, studies of household food demand using the QUAIDS approach are at province level and its analysis divided based on settlement type, urban and rural regions only. The additional quantile income groups as unit of analysis would explore deeper insight how the household consumption patterns, and behavior are affected price changes as well as by their income. The fact of using household data is important because managing food security requires not only understanding how policies influence the availability of food and income at national level but also how individual households' response with income change and price shocks.

The main objective of this study is to analyze the impact of price changes on animal source food demand in various quintile of income and settlement types, urban and rural. Through this quintile analysis, it will be known which households are the most affected by increasing the animal source food prices. The income and price elasticities of each animal source food, will reflect the nature of each animal source food, including normal, inferior or luxury goods as well as price-elastic or price-inelastic. The income elasticities, uncompensated and compensated price elasticities will be used as a basis reference for policy makers in developing recommendation and implementing strategies in order to meet RDA protein.

\section{Literature review}

Research on food demand systems has been carried out from time to time, starting from demand using simple linear regression analysis, multiple linear regression, LES (Linear Expenditure System) model, Rotterdam model, Translog model, to AIDS model (Almost Ideal Demand System) and QUAIDS (Quadratic Almost Ideal Demand System). Many researches on the impact of price changes on demand using the QUAIDS model have been carried out in various countries around the world including Indonesia Pangaribowo (2010). Pangaribowo (2010) found that animal source food is still a luxury item, which is substituted between the staple and other foods. Similar result also happened in Vietnam, Kenya, Cameroon, Ghana, Malaysia and other countries. They examined that proteinbased food sources demand as a whole context and animal food alone, were still luxury goods, especially beef except in South Africa.

There were several empirical studies using QUAIDS approach, i.e. conducted by Banks, Blundell, and Lewbel (1997), Elijah Obayelu, Okoruwa, and Ajani (2009), Pangaribowo and Tsegai (2011), Bett et al. (2012), Abbiritti et al. (2013), Akaichi and Revoredo-Giha (2014), Graham and Glaister (2004), Tefera et al. (2018) and Korir, Rizov, and Ruto (2018). Generally, they concluded that animal source food in developing countries is income-elastic and in some case even very income-elastic, since their income elasticities are greater than one. Unlike in developed countries, the demand of animal source food is price-elastic and but mostly the price elasticity is close one. Only egg is normal good since price inelastic. Generally speaking, animal source foods in developing countries were elastic, luxury goods but towards normal goods.

\section{QUAIDS (Quadratic Almost Ideal Demand System)}

The QUAIDS model being consistent with demand theory assumptions, it can also allow for non-linear Engel relationships between food group expenditure shares and food expenditure (Banks, Blundell, \& Lewbel, 1997). Ignoring such nonlinear relationships could cause parameter estimates to be inconsistent (Banks et al., 1997). The QUAIDS model will be appropriate when the joint significance of the parameter capturing the quadratic term of income on food group share, for all the food group equations is significantly different from zero.

Following Deaton and Muellbauer (1980), food and non-food expenditures are assumed to be weakly 
separable. The Quadratic Almost Ideal Demand System (QUAIDS), developed by Banks, Blundell, and Lewbel (1997), which was further augmented with demographic variables by Poi (201), is used to estimate price and food expenditure elasticities in the second stage. QUAIDS has been widely applied in the literature on food demand analysis. Using the Quadratic Almost Ideal Demand System (QUAIDS) augmented with demographic and other controls to examine the household food demand patterns, and thus availability and access to food, across income groups and types of region.

\section{Methods}

This research used the secondary data from SUSENAS (Survei Sosial Ekonomi Nasional or National Socio-Economic Survey) in March 2016 which covers of thirty-four provinces and the samples cover 291,414 households in total. The data variables included in the analysis were the consumption of animal source foods and the household expenditure on animal source foods, i.e. eggs, chicken meat, beef, fishes and powdered milk. The required socio demographic data were households' settlement type - rural/urban, number of households' members, and households' consumption and expenditure.

A new application for the development of AIDS models called the QUAIDS model which is directed at finding a framework for animal food demand models in Indonesia. Throughout the review of the latest literature, such research is still rarely found in Indonesia, especially related to the application of the QUAIDS model to various quintiles income groups. Mostly the QUAIDS model applied at province level by considering the settlement type only. The estimation of QUAIDS demand equations following Poi (2012) with STATA 14.2, using non-linear, seemingly unrelated regression approach.

Theoretically, the QUAIDS model that has been applied in several studies can be combined with welfare analysis and poverty analysis. Related with welfare analysis, the concepts of compensating variation (CV), equivalent variation (EV) and consumer surplus will be applied. In measuring the impact of price changes on poverty, we can use concept developed by Son and Kakwani (2009). Integration of all these approaches will not only provide impact price changes on "animal source foods" demand and consumption behavior, but also insight how the impact price changes for the poor households relative to the non-poor households in order to generate pro-poor policy recommendation.

\section{Demand estimation}

The approach of estimating QUAIDS for Indonesia, using the SUSENAS 2016 household expenditure survey. On the basis of selected commodity groups, which are indexed by $i$, we estimate a system of demand equations, consisting of total of animal protein consumption expenditure $m$, expenditure shares $w_{i}$ and commodity prices $p_{i}$.
The income and price elasticities estimation using settlement type and quintile total expenditure per capita as unit of analysis. The estimation of our system of demand equations following Poi (2012), using non-linear, seemingly unrelated regression.

The QUAIDS model is an AIDS model development. AIDS was discovered by (Deaton, 1980) built on the Rotterdam and Translog models. QUAIDS was developed by (Banks, Blundell, \& Lewbel, 1997). Based on the non-parametric analysis of consumer spending patterns, it appears that the Engel curve requires a higher order of logarithm expenditure. The QUAIDS model has almost the same features as AIDS and can capture the curvature of Engel. Therefore, QUAIDS has been chosen as the demand model for estimated empirical strategies. As with the general demand system model, the AIDS model is determined by the following food budget shares $\left(w_{i}\right)$ :

$$
w_{i} \equiv \frac{p_{i} q_{i}}{m},
$$

where $p_{i}$ is price of $i, q_{i}$ is quantity of $i$, and $m$ is total expenditure, so demand system:

$$
w_{i}=\alpha_{i}+\sum_{j=1}^{k} \gamma_{i j} i n p_{j}+\beta_{i} \ln \left[\frac{m}{a(p)}\right],
$$

where $p_{j}$ is price of $j$ and a $(p)$ is index price of total expenditure:

$$
\ln \alpha(p) \equiv \alpha_{0}+\sum_{i=1}^{k} \alpha_{i} \ln p_{i}+\frac{1}{2} \sum_{i=1}^{k} \sum_{j=1}^{k} \gamma_{i j} \ln p_{i} \ln p_{j}
$$

As well as the AIDS Model, the QUAIDS model also needs restrictions to be consistent with utility maximization, i.e.:

$$
\begin{aligned}
& \text { Adding up: } \sum_{i=1}^{k} \alpha_{1}=1 \sum_{i=1}^{k} \beta_{i}=0 \quad \sum_{i=1}^{k} \gamma_{i j}=0 \quad \forall j ; \\
& \text { Homogeneity: } \sum_{j=1}^{k} \gamma_{i j}=0 \quad \forall j \text {, and; } \\
& \text { Slutsky's symmetry: } \gamma_{i j}=\gamma_{j i} .
\end{aligned}
$$

Restriction on demand theory (4), (5) and (6) are imposed during estimation and ensure that notation (3) defines $\alpha(p)$ as a linearly homogeneus function af the individual prices. Futher, where notation (4), (5) and (6) hold, notation (2) provides a system of demand function which add up to total expenditure $\left(\sum w_{i}=1\right)$, is homogen as long as prices and income are zero according to the Slutsky Symmetry theory (Deaton \& Meullbauer, 1980). So, that the AIDS model can interpreted: as price $\left(p_{j}\right)$ and real expenditure $\left(\frac{m}{\alpha(p)}\right)$ is not change, so share of expenditure $\left(w_{i}\right)$ is constant $\left(\alpha_{i}\right)$.

A development of the AIDS model, the QUAIDS model was proposed by Banks et al. (1997), namely by adding an element of quadratic logarithm of expenditure. This follows the nature of flexibility the Engel curve share of 
household expenditure is not linear, and some commodities are staple goods and some commodities are luxury goods (Banks et al., 1997). The QUAIDS model in budget share is:

$w_{i}=\alpha_{i}+\sum_{j=1}^{K} \gamma_{i j} \ln p_{j}+\beta_{i} \ln \left[\frac{m}{\alpha(p)}\right]+\frac{\lambda_{i}}{b(p)}\left\{\ln \left[\frac{m}{\alpha(p)}\right]\right\}^{2}$.

The term equals equation (2) and b (p) is the CobbDouglas aggregate price, written as follows:

$$
b(p)=\prod_{j=1}^{K} \rho_{j}^{\beta_{i}} .
$$

In the consumer demand theory, adding-up conditions are also needed:

$$
\sum_{j=1}^{K} \lambda_{j}=0 .
$$

When entering the household socio-demographic variable, use the Roy method (1983) based on the expenditure function (cost) as follows:

$$
e(p, z, u)=m_{o}(p, z, u) \times e^{R}(p, u),
$$

where $z$ is a vector of household characteristics, $e^{R}(p, u)$ is expenditure function, and $m_{0}(p, z, u)$ scale of the expenditure function that can be obtained from:

$$
\bar{m}_{0}(p, z, u)=m_{o}(z) \bar{\phi}(p, z, u),
$$

where $m_{0}$ measure the increase in household expenditure as a function of $z$, and $\phi$ is a change in the price of goods consumed. So, $\bar{m}_{0}(z)$ is:

$$
\bar{m}_{0}(z)=1+\rho z
$$

where $\rho$ is a vector estimate parameters, $\varnothing(p, z, u)$ is a parameter of:

$$
\ln \phi(p, z, u)=\frac{\prod_{j=1}^{K} \rho_{j}^{\beta_{i}}\left(\prod_{j=1}^{K} \rho_{j}^{n_{i z}}-1\right)}{\frac{1}{u}-\sum_{j=1}^{K} \lambda_{j} \ln p_{j}},
$$

where $\eta_{j}$ describes the column to $j$ of the matrix parameter $\eta$. To adhere to consumer demand theory, a further adding-up condition is required, given as

$$
\sum_{j=1}^{K} \lambda_{j} \ln p_{j}+\left(\beta_{i}+\eta_{i}^{\prime} z\right) \ln ,
$$

for $r=1 \ldots, s$. The estimation of the QUAIDS animal food model can be written into the formula:

$$
\begin{aligned}
& w_{i}=\alpha_{i}+\sum_{j=1}^{K} \lambda_{j} \ln p_{j}+ \\
& {\left[\frac{m}{\alpha(p 0) \bar{m}_{0}(z)}\right]+\frac{\lambda_{i}}{b(p) c(p, z)}\left\{\ln \left[\frac{m}{\alpha(p 0) \bar{m}_{0}(z)}\right]\right\}^{2}+\varepsilon,}
\end{aligned}
$$

where

$$
c(p, z)=\prod_{j=1}^{K} \rho_{j}^{n_{i z}}
$$

The parameters generated from the QUAIDS model are used to calculate the own-price elasticity of both Hicksian and Marshallian, expenditure elasticity and cross price elasticity.

Marshallian price elasticity (Uncompensated) is:

$$
\begin{gathered}
\epsilon_{i j}^{u}=-\delta_{i j}+\frac{1}{w_{i}}\left(\gamma_{i j}-\left[\beta_{i}+\eta_{i} z+\frac{2 \lambda_{i}}{b(p) c(p, z)} \ln \left\{\frac{m}{\alpha(p 0) \bar{m}_{0}(z)}\right\}\right] \times\right. \\
\left.\left(\alpha_{j}+\sum_{1} \gamma_{j 1} \ln p_{1}\right)-\frac{\left(\beta_{i}+\eta_{j} z\right) \lambda_{i}}{b(p) c(p, z)}\left[\ln \left\{\frac{m}{\alpha(p 0) \bar{m}_{0}(z)}\right\}\right]^{2}\right] .
\end{gathered}
$$

Income elasticity is:

$\mu_{i}=1+\frac{1}{w_{i}}\left[\beta_{i}+\eta_{i} z+\frac{2 \lambda_{i}}{b(p) c(p, z)} \ln \left\{\frac{m}{\alpha(p) \bar{m}_{0}(z)}\right\}\right]$.

Hicksian elasticity (Compensated) is:

$$
\epsilon_{i j}^{c}=\epsilon_{i j}^{u}+w_{j} \mu_{i} .
$$

Equation (1) to (6) adopted from Deaton and $\mathrm{Mu}-$ ellbauer (1980), equation (7) to (19) adopted from (Poi, 2012) with reference to Banks et al. (1997).

\section{Data and composite commodity groups}

We aggregate commodity varieties and define a total of five composite commodity "protein sources animal food" groups (Table 1). The five composite commodity groups are eggs, chicken meat, beet, fish and powdered milk. The selection of the commodity groups considering the animal food as important source of animal protein for improvement of nutrition status.

Table 1. Definition of the commodity animal source food groups

\begin{tabular}{|c|l|l|}
\hline Group & Group name & \multicolumn{1}{|c|}{ Goods/items } \\
\hline 1 & Eggs & $\begin{array}{l}\text { Chicken eggs, free-range chicken eggs, } \\
\text { duck eggs }\end{array}$ \\
\hline 2 & $\begin{array}{l}\text { Chicken } \\
\text { Meat }\end{array}$ & $\begin{array}{l}\text { Broiler chicken meat, free-range } \\
\text { chicken meat }\end{array}$ \\
\hline 3 & Beef & Beef \\
\hline 4 & Fishes & Fish, shrimp, squid and shellfish \\
\hline 5 & $\begin{array}{l}\text { Powdered } \\
\text { Milk }\end{array}$ & $\begin{array}{l}\text { Infant milk powdered; formula milk } \\
\text { powdered }\end{array}$ \\
\hline
\end{tabular}

Note: Modified from the National Bureau of Statistics classifications. 


\section{Rural urban and quintiles unit analysis}

We are particularly interested in income and price elasticities of animal sources protein based on settlement types and income (total expenditure) quintiles. Price differences between the animal source food categories of egg, chicken meat, beef, fishes, and powdered milk to have an impact on income and price elasticities. Therefore, we estimate income and price elasticities based on settlement type as well as quintiles. It is expected there would be different between rural and urban, as well as taken into account for the differences among quintiles of income.

\section{Expenditure shares and total expenditure}

The expenditure shares for each commodity group is calculate as a ratio of expenditure on the commodity group $i$ and the total of animal food expenditure $e$. The total household expenditure $e$ as the aggregate expenditure value of the animal source foods commodities, as defined in Table 1. The per capita total expenditure is then defined as the ratio of total expenditure and household size. The calculation of the total consumption expenditure on the basis of the so-called mixed recall period, as available in the SUSENAS data. The mixed recall period of food consumption comprises a 7 days (week) recall period for food items and a 30 days recall period for non-food items (Susenas, 2016).

\section{Unit values and price indices}

A weighted composite group price for each commodity group $i$, by using the quantities and values of purchased goods, which are reported in the SUSENAS survey. Both values will be used to generate implicit unit values or prices at the household level. Unit values are defined as the ratio of expenditure and weighted quantity and use them to calculate weighted composite group prices.

\section{Results}

\subsection{Descriptive analysis}

This research (Table 2-5) first examines that the lowest income group lacked the largest protein, amounting to 16.55 gram/cap/day (29.04\%), while the highest income group had excess protein at $19.88 \mathrm{gram} / \mathrm{cap} /$ day $(34.88 \%)$. The highest expenditure was seen in the lowest income household group, namely grains by $29.65 \%$. The food budget share of grains and tubers tends to decrease with increasing household income. Whereas the food budget share of animal/fish/shrimp etc., meat, eggs, and milk are $7.30 \%, 4.46 \%$, and $6.08 \%$ respectively, and tends to increase along with the increasing income.

Table 2. The expenditure of each food group and its share to total food expenditure by settlement type (source: author' computation from Susenas, 2016)

\begin{tabular}{|l|c|c|c|c|c|c|c|c|c|c|}
\hline \multicolumn{1}{|c|}{ Food Groups } & Cereals & $\begin{array}{c}\text { Fish, } \\
\text { shrimp etc. }\end{array}$ & Meat & $\begin{array}{c}\text { Eggs \& } \\
\text { Milk }\end{array}$ & Pulses & $\begin{array}{c}\text { Cooking } \\
\text { Oil \& } \\
\text { coconut }\end{array}$ & $\begin{array}{c}\text { Prepared } \\
\text { Food \& } \\
\text { Beverage }\end{array}$ & $\begin{array}{c}\text { Other } \\
\text { foods }\end{array}$ & $\begin{array}{c}\text { Total All } \\
\text { Foods }\end{array}$ \\
\hline Settlement Type & \multicolumn{7}{|c|}{ Food Expenditure (Rp/capita/month) } \\
\hline Urban & $\mathbf{5 8 , 1 2 2}$ & 35,799 & 26,902 & 35,757 & 11,358 & 12,331 & $\mathbf{1 7 7 , 7 7 5}$ & $\mathbf{9 8 , 8 9 1}$ & $\mathbf{4 5 6 , 9 3 5}$ \\
\hline Rural & $\mathbf{7 1 , 3 9 0}$ & 31,313 & 13,774 & 19,835 & 9,280 & 13,101 & $\mathbf{8 7 , 2 9 6}$ & $\mathbf{8 7 , 7 0 6}$ & $\mathbf{3 3 3 , 6 9 5}$ \\
\hline All urban rural & $\mathbf{6 4 , 5 6 6}$ & $\mathbf{3 3 , 6 2 0}$ & $\mathbf{2 0 , 5 2 7}$ & $\mathbf{2 8 , 0 2 5}$ & $\mathbf{1 0 , 3 4 9}$ & $\mathbf{1 2 , 7 0 5}$ & $\mathbf{1 3 3 , 8 3 4}$ & $\mathbf{9 3 , 4 5 9}$ & $\mathbf{3 9 7 , 0 8 4}$ \\
\hline Settlement Type & \multicolumn{7}{|c|}{ Share (\%) to total foods expenditure (Rp/capita/month) } \\
\hline Urban & 12.7 & 7.8 & 5.9 & 7.8 & 2.5 & 2.7 & 38.9 & $\mathbf{2 1 . 6}$ & $\mathbf{1 0 0 . 0}$ \\
\hline Rural & 21.4 & 9.4 & 4.1 & 5.9 & 2.8 & 3.9 & 26.2 & $\mathbf{2 6 . 3}$ & $\mathbf{1 0 0 . 0}$ \\
\hline All urban rural & $\mathbf{1 6 . 3}$ & $\mathbf{8 . 5}$ & $\mathbf{5 . 2}$ & $\mathbf{7 . 1}$ & $\mathbf{2 . 6}$ & $\mathbf{3 . 2}$ & $\mathbf{3 3 . 7}$ & $\mathbf{2 3 . 5}$ & $\mathbf{1 0 0 . 0}$ \\
\hline
\end{tabular}

Table 3. The expenditure of each food group and its share to total food expenditure by income quintile (source: author' computation from Susenas, 2016)

\begin{tabular}{|l|c|c|c|c|c|c|c|c|c|}
\hline \multicolumn{1}{|c|}{ Food Groups } & Cereals & $\begin{array}{c}\text { Fish, } \\
\text { shrimp } \\
\text { etc. }\end{array}$ & Meat & $\begin{array}{c}\text { Eggs \& } \\
\text { Milk }\end{array}$ & Pulses & $\begin{array}{c}\text { Cooking } \\
\text { Oil \& } \\
\text { coconut }\end{array}$ & $\begin{array}{c}\text { Prepared } \\
\text { Food \& } \\
\text { Beverage }\end{array}$ & $\begin{array}{c}\text { Other } \\
\text { foods }\end{array}$ & $\begin{array}{c}\text { Total All } \\
\text { Foods }\end{array}$ \\
\hline Income Quintile & \multicolumn{7}{|c|}{ Food Expenditure (Rp/capita/month) } \\
\hline Q1. <20\% (lowest) & 51,303 & 12,987 & 3,903 & 8,290 & 6,314 & 7,488 & 38,229 & $\mathbf{4 3 , 7 2 0}$ & $\mathbf{1 7 2 , 2 3 3}$ \\
\hline Q2. 20-40\% & 58,648 & 20,772 & 7,851 & 14,070 & 8,108 & 9,983 & 66,432 & $\mathbf{6 2 , 6 5 2}$ & $\mathbf{2 4 8 , 5 1 5}$ \\
\hline Q3. 40-60\% & 67,327 & 30,538 & 13,749 & 21,442 & 9,813 & 12,562 & 98,090 & $\mathbf{8 4 , 8 6 1}$ & $\mathbf{3 3 8 , 3 8 2}$ \\
\hline
\end{tabular}


End of Table 3

\begin{tabular}{|c|c|c|c|c|c|c|c|c|c|}
\hline Food Groups & Cereals & $\begin{array}{l}\text { Fish, } \\
\text { shrimp } \\
\text { etc. }\end{array}$ & Meat & $\begin{array}{c}\text { Eggs \& } \\
\text { Milk }\end{array}$ & Pulses & $\begin{array}{l}\text { Cooking } \\
\text { Oil \& } \\
\text { coconut }\end{array}$ & $\begin{array}{l}\text { Prepared } \\
\text { Food \& } \\
\text { Beverage }\end{array}$ & $\begin{array}{l}\text { Other } \\
\text { foods* }\end{array}$ & $\begin{array}{c}\text { Total All } \\
\text { Foods }\end{array}$ \\
\hline Q4. 60-80\% & 72,134 & 41,737 & 23,969 & 33,241 & 12,459 & 15,477 & 152,895 & 114,485 & 466,397 \\
\hline Q5. >80\% (highest) & 73,419 & 62,070 & 53,164 & 63,083 & 15,050 & 18,017 & 313,538 & 161,585 & 759,927 \\
\hline Total & 64,566 & 33,620 & 20,527 & 28,025 & 10,349 & 12,705 & 133,834 & 93,459 & 397,084 \\
\hline Income Quintile & \multicolumn{9}{|c|}{ Share (\%) to total foods expenditure (Rp/capita/month) } \\
\hline Q1. <20\% (lowest) & 29.8 & 7.5 & 2.3 & 4.8 & 3.7 & 4.3 & 22.2 & 25.4 & 100.0 \\
\hline Q2. 20-40\% & 23.6 & 8.4 & 3.2 & 5.7 & 3.3 & 4.0 & 26.7 & 25.2 & 100.0 \\
\hline Q3. $40-60 \%$ & 19.9 & 9.0 & 4.1 & 6.3 & 2.9 & 3.7 & 29.0 & 25.1 & 100.0 \\
\hline Q4. 60-80\% & 15.5 & 8.9 & 5.1 & 7.1 & 2.7 & 3.3 & 32.8 & 24.5 & 100.0 \\
\hline Q5. >80\% (highest) & 9.7 & 8.2 & 7.0 & 8.3 & 2.0 & 2.4 & 41.3 & 21.3 & 100.0 \\
\hline Total & 16.3 & 8.5 & 5.2 & 7.1 & 2.6 & 3.2 & 33.7 & 23.5 & 100.0 \\
\hline
\end{tabular}

Table 4. The protein consumption across each food group and its share to total protein consumption by settlement type (source: author' computation from Susenas, 2016)

\begin{tabular}{|c|c|c|c|c|c|c|c|c|c|}
\hline Food Groups & Cereals & $\begin{array}{l}\text { Fish, } \\
\text { shrimp } \\
\text { etc. }\end{array}$ & Meat & $\begin{array}{c}\text { Eggs \& } \\
\text { Milk }\end{array}$ & Pulses & $\begin{array}{l}\text { Cooking } \\
\text { Oil \& } \\
\text { coconut }\end{array}$ & $\begin{array}{c}\text { Prepared } \\
\text { Food \& } \\
\text { Beverage }\end{array}$ & $\begin{array}{l}\text { Other } \\
\text { foods* }\end{array}$ & $\begin{array}{c}\text { Total All } \\
\text { Foods }\end{array}$ \\
\hline Settlement Type & \multicolumn{9}{|c|}{ Protein consumption (gram/capita/day) } \\
\hline Urban & 18.91 & 7.03 & 4.28 & 4.18 & 5.44 & 0.15 & 14.08 & 5.07 & 59.14 \\
\hline Rural & 23.40 & 7.32 & 2.36 & 2.46 & 4.47 & 0.32 & 8.26 & 5.46 & 54.05 \\
\hline All urban rural & 21.09 & 7.17 & 3.35 & 3.34 & 4.97 & 0.24 & 11.25 & 5.26 & 56.67 \\
\hline Settlement Type & \multicolumn{9}{|c|}{ Share (\%) to total protein consumption gram/capita/day } \\
\hline Urban & 32.0 & 11.9 & 7.2 & 7.1 & 9.2 & 0.3 & 23.8 & 8.6 & 100.0 \\
\hline Rural & 43.3 & 13.6 & 4.4 & 4.5 & 8.3 & 0.6 & 15.3 & 10.1 & 100.0 \\
\hline All urban rural & 37.2 & 12.7 & 5.9 & 5.9 & 8.8 & 0.4 & 19.9 & 9.3 & 100.0 \\
\hline
\end{tabular}

Table 5. The protein consumption across each food group and its share to total protein consumption by income quintile (source: author' computation from Susenas, 2016)

\begin{tabular}{|c|c|c|c|c|c|c|c|c|c|}
\hline Food Groups & Cereals & $\begin{array}{l}\text { Fish, } \\
\text { shrimp } \\
\text { etc. }\end{array}$ & Meat & $\begin{array}{c}\text { Eggs \& } \\
\text { Milk }\end{array}$ & Pulses & $\begin{array}{l}\text { Cooking } \\
\text { Oil \& } \\
\text { coconut }\end{array}$ & $\begin{array}{c}\text { Prepared } \\
\text { Food \& } \\
\text { Beverage }\end{array}$ & $\begin{array}{l}\text { Other } \\
\text { foods }\end{array}$ & $\begin{array}{c}\text { Total All } \\
\text { Foods }\end{array}$ \\
\hline Income Quintile & \multicolumn{9}{|c|}{ Protein consumption (gram/capita/day) } \\
\hline Q1. <20\% (lowest) & 20.32 & 4.34 & 0.94 & 1.46 & 3.89 & 0.19 & 5.35 & 3.96 & 40.45 \\
\hline Q2. 20-40\% & 21.11 & 5.86 & 1.80 & 2.23 & 4.59 & 0.24 & 7.76 & 4.70 & 48.29 \\
\hline Q3. 40-60\% & 22.11 & 7.24 & 2.80 & 2.91 & 4.85 & 0.26 & 9.63 & 5.24 & 55.04 \\
\hline Q4. 60-80\% & 21.79 & 8.39 & 4.15 & 3.95 & 5.55 & 0.27 & 12.65 & 5.93 & 62.68 \\
\hline Q5. > 80\% (highest) & 20.11 & 10.02 & 7.06 & 6.17 & 5.97 & 0.22 & 20.87 & 6.46 & 76.88 \\
\hline Total & 21.09 & 7.17 & 3.35 & 3.34 & 4.97 & 0.24 & 11.25 & 5.26 & 56.67 \\
\hline Income Quintile & \multicolumn{9}{|c|}{ Share (\%) to total protein consumption gram/capita/day } \\
\hline Q1. <20\% (lowest) & 50.2 & 10.7 & 2.3 & 3.6 & 9.6 & 0.5 & 13.2 & 9.8 & 100.0 \\
\hline Q2. 20-40\% & 43.7 & 12.1 & 3.7 & 4.6 & 9.5 & 0.5 & 16.1 & 9.7 & 100.0 \\
\hline Q3. 40-60\% & 40.2 & 13.2 & 5.1 & 5.3 & 8.8 & 0.5 & 17.5 & 9.5 & 100.0 \\
\hline Q4. 60-80\% & 34.8 & 13.4 & 6.6 & 6.3 & 8.9 & 0.4 & 20.2 & 9.5 & 100.0 \\
\hline Q5. >80\% (highest) & 26.2 & 13.0 & 9.2 & 8.0 & 7.8 & 0.3 & 27.1 & 8.4 & 100.0 \\
\hline Total & 37.2 & 12.7 & 5.9 & 5.9 & 8.8 & 0.4 & 19.9 & 9.3 & 100.0 \\
\hline
\end{tabular}




\subsection{Demand model}

The results of the estimation of QUAIDS parameters are presented in the Table 6 . The estimated parameters of the QUAIDS demand system indicate the fit of the model, and the majority is significant at the 1 per cent level, except gamma for beef (5\%). It means all QUAIDS parameter different from zero. Since the parameters are difficult to interpret, we continue with the calculation of income elasticities, and the discussion will be presented in next section.

Statistical significance of the log-price coefficients has interesting pattern. Coefficients near real expenditures squared are naturally lower in magnitude than those of linear expenditure terms.

\subsection{Demographic effect}

Household size had lower impact, and vast majority coefficients are very close to zero.

From the animal source foods demand point of view, such results are truly expectable: the most influences on the consumer choice is made by settlement type, as in correspondence to that the meat supply really differs. Consumer choice/demand also influenced by the size of household, taking into account effect of scale.

\subsection{Income elasticities and own price elasticity}

Income elasticities are evaluated at the mean income by settlement types and quintiles of total expenditure per capita. Income elasticities show the percentage change in quantity demanded after a one percent change in income (expenditure).

For all type of settlement types, the income elasticity for commodity groups like chicken meat, beef, fishes and powdered milk is greater than one and are luxurious goods, except eggs is between zero and one and are thus normal goods. Since the income elasticity of eggs is lower than one, eggs are necessities.

\section{Income and price elasticities by settlement type}

The expenditure and own-price Marshallian and Hicksian elasticities are presented in Table 7. All own-price elasticities, both compensated and uncompensated, are negative for all animal source foods, in lined with the theory.

Expenditure elasticities are positive and differ for different types of animal source foods. Expenditure elasticity of beef is highest, then the follow by fishes, and chicken meat and finally eggs. We definitely see, that the demand for chicken meat, beef, fishes and powdered milk is income-elastic, while demand for eggs is income-inelastic.

\section{Differences in meat demand of urban and rural households}

The demand of chicken meat, beef, fishes and powdered milk are still income-elastic for both urban and rural, while only eggs is not.

\section{Income and price elasticities by quintiles}

In term of income elasticity, most of animal source foods are luxurious, except for eggs that is normal good (Table 8).

Table 6. The estimation of QUAIDS parameters Indonesia all households sample (source: author' computation from Susenas, 2016)

\begin{tabular}{|c|c|c|c|c|c|c|c|c|c|c|}
\hline \multirow{2}{*}{$\begin{array}{l}\text { Parameter } \\
\text { (Coefficient) }\end{array}$} & \multicolumn{2}{|c|}{ Eggs } & \multicolumn{2}{|c|}{ Chicken Meat } & \multicolumn{2}{|c|}{ Beef } & \multicolumn{2}{|c|}{ Fishes } & \multicolumn{2}{|c|}{ Powdered Milk } \\
\hline & Coef. & $\mathrm{P}>|\mathrm{z}|$ & Coef. & $P>|z|$ & Coef. & $\mathrm{P}>|\mathrm{z}|$ & Coef. & $\mathrm{P}>|\mathrm{z}|$ & Coef. & $\mathrm{P}>|\mathrm{z}|$ \\
\hline \multicolumn{11}{|l|}{ Alpha } \\
\hline & 0.5662 & 0.000 & -1.3408 & 0.000 & 0.7284 & 0.000 & 0.0178 & 0.157 & 1.0284 & 0.000 \\
\hline \multicolumn{11}{|c|}{ Beta - Linier Expenditure } \\
\hline & 0.0450 & 0.000 & -0.3176 & 0.000 & 0.1217 & 0.000 & -0.0115 & 0.000 & 0.1624 & 0.000 \\
\hline \multicolumn{11}{|l|}{ Gamma Price } \\
\hline Eggs & 0.3985 & 0.000 & -0.2589 & 0.000 & -0.0058 & 0.013 & -0.0390 & 0.000 & -0.0947 & 0.000 \\
\hline Chicken meat & -0.2589 & 0.000 & 0.5684 & 0.000 & -0.1921 & 0.000 & 0.0701 & 0.000 & -0.1875 & 0.000 \\
\hline Beef & -0.0058 & 0.013 & -0.1921 & 0.000 & 0.0597 & 0.000 & 0.0115 & 0.000 & 0.1267 & 0.000 \\
\hline Freshes & -0.0390 & 0.000 & 0.0701 & 0.000 & 0.0115 & 0.000 & -0.0517 & 0.000 & 0.0091 & 0.000 \\
\hline Powdered milk & -0.0947 & 0.000 & -0.1875 & 0.000 & 0.1267 & 0.000 & 0.0091 & 0.000 & 0.1465 & 0.000 \\
\hline \multicolumn{11}{|c|}{ Lambda - Quadratic Expenditure } \\
\hline & 0.0154 & 0.000 & -0.0214 & 0.000 & 0.0046 & 0.000 & -0.0018 & 0.000 & 0.0033 & 0.000 \\
\hline \multicolumn{11}{|c|}{ Eta - Demographic Effect on Demand } \\
\hline Urban/Rural & 0.0019 & 0.000 & -0.0038 & 0.000 & 0.0005 & 0.000 & 0.0011 & 0.000 & 0.0003 & 0.000 \\
\hline Household Size & -0.0007 & 0.000 & 0.0011 & 0.000 & 0.0002 & 0.000 & 0.0001 & 0.000 & -0.0007 & 0.000 \\
\hline \multicolumn{11}{|c|}{ Rho - Demographic Effect on Expenditure } \\
\hline Urban/Rural & 0.1112 & 0.000 & 0.1112 & 0.000 & 0.1112 & 0.000 & 0.1112 & 0.000 & 0.1112 & 0.000 \\
\hline Household Size & 0.0853 & 0.000 & 0.0853 & 0.000 & 0.0853 & 0.000 & 0.0853 & 0.000 & 0.0853 & 0.000 \\
\hline
\end{tabular}


Table 7. Expenditure and own price elasticities across commodities by settlement types (source: author' computation from Susenas, 2016)

\begin{tabular}{|c|c|c|c|c|c|c|c|c|c|c|}
\hline \multirow{2}{*}{$\begin{array}{l}\text { Settlement } \\
\text { Type }\end{array}$} & \multicolumn{10}{|c|}{ Animal-source Foods } \\
\hline & \multicolumn{2}{|c|}{ Eggs } & \multicolumn{2}{|c|}{ Chicken Meat } & \multicolumn{2}{|c|}{ Beef } & \multicolumn{2}{|c|}{ Fishes } & \multicolumn{2}{|c|}{ Powdered Milk } \\
\hline $\begin{array}{l}\text { Settlement } \\
\text { Type }\end{array}$ & \multicolumn{10}{|c|}{ Uncompensated Own Price Elasticities (Marshallian) } \\
\hline Urban & -0.7492 & $(0.0043)$ & -1.4021 & $(0.0096)$ & -1.9750 & $(0.0255)$ & -1.9793 & $(0.0142)$ & -1.5609 & $(0.0109)$ \\
\hline Rural & -0.8361 & $(0.0032)$ & -1.7430 & $(0.0108)$ & -3.3268 & $(0.0617)$ & -2.4594 & $(0.0209)$ & -1.9212 & $(0.0196)$ \\
\hline All & -0.8015 & $(0.0035)$ & -1.5670 & $(0.0087)$ & -2.4090 & $(0.0372)$ & -2.1925 & $(0.0172)$ & -1.7000 & $(0.0142)$ \\
\hline $\begin{array}{l}\text { Settlement } \\
\text { Type }\end{array}$ & \multicolumn{10}{|c|}{ Compensated Own Price Elasticities (Hicksian) } \\
\hline Urban & -0.5178 & $(0.0043)$ & -1.0156 & $(0.0095)$ & -1.9015 & $(0.0255)$ & -1.8969 & $(0.0142)$ & -1.3347 & $(0.0108)$ \\
\hline Rural & -0.4754 & $(0.0032)$ & -1.3801 & $(0.0107)$ & -3.2821 & $(0.0617)$ & -2.3920 & $(0.0209)$ & -1.7568 & $(0.0196)$ \\
\hline All & -0.5004 & $(0.0034)$ & -1.1932 & $(0.0087)$ & -2.3511 & $(0.0372)$ & -2.1181 & $(0.0172)$ & -1.5072 & $(0.0142)$ \\
\hline $\begin{array}{l}\text { Settlement } \\
\text { Type }\end{array}$ & \multicolumn{10}{|c|}{ Expenditure (income) Elasticities } \\
\hline Urban & 0.4759 & $(0.0011)$ & 1.3461 & $(0.0023)$ & 1.8853 & $(0.0066)$ & 1.4112 & $(0.0054)$ & 1.7489 & $(0.0035)$ \\
\hline Rural & 0.5678 & $(0.0008)$ & 1.5305 & $(0.0025$ & 2.7848 & $(0.0150)$ & 1.6948 & $(0.0074)$ & 2.2906 & $(0.0059)$ \\
\hline All & 0.5315 & $(0.0008)$ & 1.4367 & $(0.0021$ & 2.1779 & $(0.0086)$ & 1.5380 & $(0.0061)$ & 1.9624 & $(0.0042)$ \\
\hline
\end{tabular}

Note: (...) standard error of mean.

Table 8. Expenditure and own price elasticities across commodities by income quintile (source: author' computation from Susenas, 2016)

\begin{tabular}{|c|c|c|c|c|c|c|c|c|c|c|}
\hline \multirow{3}{*}{$\begin{array}{c}\text { Income Quintile } \\
\text { Income Quintile }\end{array}$} & \multicolumn{10}{|c|}{ Animal-source Foods } \\
\hline & \multicolumn{2}{|c|}{ Eggs } & \multicolumn{2}{|c|}{ Chicken Meat } & \multicolumn{2}{|c|}{ Beef } & \multicolumn{2}{|c|}{ Fishes } & \multicolumn{2}{|c|}{ Powdered Milk } \\
\hline & \multicolumn{10}{|c|}{ Uncompensated Own Price Elasticities (Marshallian) } \\
\hline Q1. <20\% (lowest) & -0.9109 & $(0.0028)$ & -2.5402 & $(0.0155)$ & -7.4820 & $(0.1584)$ & -3.1139 & $(0.0286)$ & -2.2046 & $(0.0250)$ \\
\hline Q2. 20-40\% & -0.8687 & $(0.0029)$ & -1.9574 & $(0.0108)$ & -5.4536 & $(0.1105)$ & -2.7375 & $(0.0248)$ & -2.0375 & $(0.0209)$ \\
\hline Q3. $40-60 \%$ & -0.8235 & $(0.0032)$ & -1.6443 & $(0.0089)$ & -4.1097 & $(0.0798)$ & -2.4811 & $(0.0213)$ & -1.8709 & $(0.0175)$ \\
\hline Q4. 60-80\% & -0.7524 & $(0.0039)$ & -1.3910 & $(0.0077)$ & -2.4605 & $(0.0395)$ & -2.0527 & $(0.0153)$ & -1.6699 & $(0.0136)$ \\
\hline Q5. > 80\% (highest) & -0.6277 & $(0.0054)$ & -1.2001 & $(0.0086)$ & -1.5231 & $(0.0153)$ & -1.7720 & $(0.0113)$ & -1.4350 & $(0.0089)$ \\
\hline Income Quintile & \multicolumn{10}{|c|}{ Compensated Own Elasticities (Hicksian) } \\
\hline Q1. <20\% (lowest) & -0.4634 & $(0.0028)$ & -2.2186 & $(0.0154)$ & -7.4528 & $(0.1584)$ & -3.0566 & $(0.0301)$ & -2.0603 & $(0.0250)$ \\
\hline Q2. 20-40\% & -0.4749 & $(0.0029)$ & -1.6076 & $(0.0108)$ & -5.4174 & $(0.1105)$ & -2.6763 & $(0.0248)$ & -1.8786 & $(0.0209)$ \\
\hline Q3. $40-60 \%$ & -0.4796 & $(0.0031)$ & -1.2705 & $(0.0089)$ & -4.0669 & $(0.0798)$ & -2.4156 & $(0.0213)$ & -1.6970 & $(0.0175)$ \\
\hline Q4. 60-80\% & -0.4933 & $(0.0039)$ & -0.9875 & $(0.0078)$ & -2.4017 & $(0.0395)$ & -1.9733 & $(0.0152)$ & -1.4707 & $(0.0136)$ \\
\hline Q5. > 80\% (highest) & -0.4772 & $(0.0055)$ & -0.8075 & $(0.0085)$ & -1.4199 & $(0.0153)$ & -1.6752 & $(0.0113)$ & -1.1782 & $(0.0089)$ \\
\hline Income Quintile & \multicolumn{10}{|c|}{ Expenditure (income) Elasticities } \\
\hline Q1. <20\% (lowest) & 0.6027 & $(0.0008)$ & 1.9272 & $(0.0041)$ & 4.6134 & $(0.0459)$ & 2.0657 & $(0.0131)$ & 2.5577 & $(0.0086)$ \\
\hline Q2. 20-40\% & 0.5847 & $(0.0008)$ & 1.6163 & $(0.0027)$ & 4.0274 & $(0.0267)$ & 1.8297 & $(0.0092)$ & 2.3523 & $(0.0064)$ \\
\hline Q3. $40-60 \%$ & 0.5615 & $(0.0008)$ & 1.4599 & $(0.0022)$ & 3.4553 & $(0.0184)$ & 1.6794 & $(0.0075)$ & 2.1718 & $(0.0052)$ \\
\hline Q4. 60-80\% & 0.5020 & $(0.0010)$ & 1.3373 & $(0.0020)$ & 2.3469 & $(0.0095)$ & 1.4587 & $(0.0056)$ & 1.9388 & $(0.0041)$ \\
\hline Q5. > 80\% (highest) & 0.3828 & $(0.0016)$ & 1.2635 & $(0.0023)$ & 1.5782 & $(0.0042)$ & 1.3133 & $(0.0047)$ & 1.6353 & $(0.0030)$ \\
\hline
\end{tabular}

Note: (...) standard error of mean. 
The luxuriousness of chicken meat, beef, fishes and powdered milk decrease with increasing household income level as expressed in quintile level. The high value animal food source foods, such as chicken meat, beef, fishes and powdered milk are the most sensitive to its own price change, as well as to a change in income for eggs and chicken meat.

\section{Compensated own and cross price elasticities}

In Table 9 and 10, we report compensated own and cross price elasticities, which are evaluated at the mean value. Own price elasticities are defined as the percentage change of quantity consumed after a one per cent price increase. As expected, our model yields negative own price elasticities for all animal sources food commodities.

Consequently, their demand is relatively inelastic. The change in quantity consumed is lower than the percentage change in price. This is consistent with our results of income elasticities. On the other hand, chicken milk, beef, fishes and powdered milk have an own price elasticity below -1 . Thus, the demand for these goods is relatively elastic, which means that the change in quantity demanded is larger than the percentage change in price. It means the consumption of these goods is sensitive to an own price change and a rise in prices leads to a comparatively strong decline in consumption expenditure.
The next elasticities are cross price elasticities, which are defined as the percentage change of quantity demanded of one good after a one per cent price increase of another good. A negative cross price elasticity means that the goods are complements, while a positive cross price elasticity suggest the goods to be substitutes. If the cross-price elasticity is (close to) zero, then the goods are independent and a price increase of one good does not trigger a change in consumption quantities of the other.

Based on results for income, compensated own and cross price elasticities yield important insights into consumer behavior (Table 11, 12). High income and own price elasticities show that these goods are sensitive to a price increase and the first to be substituted in case of an income decrease or a price increase.

Consequently, households consume a less diversified diet in times of high food prices and focusing their diet on more affordable commodities. High value animal sourcefoods (agricultural commodities) play an important role in a diversified and nutritionally balanced diet, since they are rich in proteins as well as essential amino acids. Indonesia's food inflation, which was led by high value agricultural commodities, therefore threatens to worsen the nutritional status of the Indonesian consumer especially in term of protein consumption status.

Table 9. Uncompensated price elasticities across commodities by settlement types (source: author' computation from Susenas, 2016)

\begin{tabular}{|c|c|c|c|c|c|c|c|c|c|c|}
\hline \multirow{3}{*}{$\begin{array}{l}\text { Settlement Type } \\
\text { Urban }\end{array}$} & \multicolumn{10}{|c|}{ Animal-source Food } \\
\hline & \multicolumn{2}{|c|}{ Eggs } & \multicolumn{2}{|c|}{ Chicken Meat } & \multicolumn{2}{|c|}{ Beef } & \multicolumn{2}{|c|}{ Fishes } & \multicolumn{2}{|c|}{ Powdered Milk } \\
\hline & \multicolumn{9}{|c|}{ Uncompensated Cross Elasticities (Marshallian) } & \\
\hline Eggs & -0.7492 & $(0.0043)$ & 0.1090 & $(0.0044)$ & 0.0475 & $(0.0019)$ & 0.0313 & $(0.0019)$ & 0.0855 & $(0.0025)$ \\
\hline Chicken Meat & -0.2536 & $(0.0072)$ & -1.4021 & $(0.0096)$ & 0.0513 & $(0.0032)$ & 0.1086 & $(0.0034)$ & 0.1497 & $(0.0046)$ \\
\hline Beef & -0.0510 & $(0.0232)$ & 0.1915 & $(0.0239)$ & -1.9750 & $(0.0255)$ & 0.3030 & $(0.0158)$ & -0.3538 & $(0.0198)$ \\
\hline Fishes & -0.1946 & $(0.0161)$ & 0.5087 & $(0.0166)$ & 0.2234 & $(0.0106)$ & -1.9793 & $(0.0142)$ & 0.0306 & $(0.0135)$ \\
\hline Powdered Milk & -0.2764 & $(0.0095)$ & 0.1959 & $(0.0102)$ & -0.0994 & $(0.0060)$ & -0.0080 & $(0.0061)$ & -1.5609 & $(0.0109)$ \\
\hline Rural & & & ' & & & & & & & \\
\hline Eggs & -0.8361 & $(0.0032)$ & 0.1645 & $(0.0031)$ & 0.0178 & $(0.0014)$ & 0.0333 & $(0.0014)$ & 0.0527 & $(0.0019)$ \\
\hline Chicken Meat & -0.1742 & $(0.0083)$ & -1.7430 & $(0.0108)$ & 0.0953 & $(0.0038)$ & 0.1119 & $(0.0041)$ & 0.1795 & $(0.0057)$ \\
\hline Beef & -0.6588 & $(0.0547)$ & 1.0866 & $(0.0558)$ & -3.3268 & $(0.0617)$ & 0.7546 & $(0.0385)$ & -0.6404 & $(0.0480)$ \\
\hline Fishes & -0.2058 & $(0.0234)$ & 0.6369 & $(0.0242)$ & 0.3259 & $(0.0155)$ & -2.4594 & $(0.0209)$ & 0.0076 & $(0.0198)$ \\
\hline Powdered Milk & -0.6142 & $(0.0173)$ & 0.4030 & $(0.0187)$ & -0.1333 & $(0.0107)$ & -0.0250 & $(0.0110)$ & -1.9212 & $(0.0196)$ \\
\hline Pooled Urban-Rural & & & & & & & & & & \\
\hline Eggs & -0.8015 & $(0.0035)$ & 0.1421 & $(0.0030)$ & 0.0296 & $(0.0015)$ & 0.0325 & $(0.0016)$ & 0.0658 & $(0.0021)$ \\
\hline Chicken Meat & -0.2145 & $(0.0069)$ & -1.5670 & $(0.0087)$ & 0.0716 & $(0.0033)$ & 0.1107 & $(0.0037)$ & 0.1626 & $(0.0050)$ \\
\hline Beef & -0.2512 & $(0.0323)$ & 0.4730 & $(0.0324)$ & -2.4090 & $(0.0372)$ & 0.4482 & $(0.0232)$ & -0.4389 & $(0.0289)$ \\
\hline Fishes & -0.1989 & $(0.0192)$ & 0.5676 & $(0.0196)$ & 0.2675 & $(0.0127)$ & -2.1925 & $(0.0172)$ & 0.0182 & $(0.0163)$ \\
\hline Powdered Milk & -0.4108 & $(0.0124)$ & 0.2744 & $(0.0133)$ & -0.1107 & $(0.0078)$ & -0.0153 & $(0.0080)$ & -1.7000 & $(0.0142)$ \\
\hline
\end{tabular}

Note: (...) standard error of mean. 
Table 10. Compensated price elasticities across commodities by settlement types (source: author' computation from Susenas, 2016)

\begin{tabular}{|c|c|c|c|c|c|c|c|c|c|c|}
\hline \multirow{2}{*}{ Settlement Type } & \multicolumn{10}{|c|}{ Animal-source Foods } \\
\hline & \multicolumn{2}{|c|}{ Eggs } & \multicolumn{2}{|c|}{ Chicken Meat } & \multicolumn{2}{|c|}{ Beef } & \multicolumn{2}{|c|}{ Fishes } & \multicolumn{2}{|c|}{ Powdered Milk } \\
\hline Urban & \multicolumn{10}{|c|}{ Compensated Cross Elasticities (Hicksian) } \\
\hline Eggs & -0.5178 & $(0.0043)$ & 0.2456 & $(0.0043)$ & 0.0661 & $(0.0019)$ & 0.0591 & $(0.0019)$ & 0.1470 & $(0.0025)$ \\
\hline Chicken Meat & 0.4008 & $(0.0073)$ & -1.0156 & $(0.0095)$ & 0.1038 & $(0.0032)$ & 0.1873 & $(0.0034)$ & 0.3238 & $(0.0046)$ \\
\hline Beef & 0.8655 & $(0.0232)$ & 0.7329 & $(0.0238)$ & -1.9015 & $(0.0255)$ & 0.4131 & $(0.0158)$ & -0.1100 & $(0.0198)$ \\
\hline Fishes & 0.4914 & $(0.0159)$ & 0.9139 & $(0.0166)$ & 0.2784 & $(0.0106)$ & -1.8969 & $(0.0142)$ & 0.2131 & $(0.0135)$ \\
\hline Powdered Milk & 0.5738 & $(0.0094)$ & 0.6981 & $(0.0102)$ & -0.0312 & $(0.0060)$ & 0.0942 & $(0.0061)$ & -1.3347 & $(0.0108)$ \\
\hline \multicolumn{11}{|l|}{ Rural } \\
\hline Eggs & -0.4754 & $(0.0032)$ & 0.2992 & $(0.0031)$ & 0.0269 & $(0.0014)$ & 0.0559 & $(0.0014)$ & 0.0934 & $(0.0019)$ \\
\hline Chicken Meat & 0.7981 & $(0.0083)$ & -1.3801 & $(0.0107)$ & 0.1198 & $(0.0038)$ & 0.1728 & $(0.0041)$ & 0.2893 & $(0.0057)$ \\
\hline Beef & 1.1104 & $(0.0541)$ & 1.7470 & $(0.0558)$ & -3.2821 & $(0.0617)$ & 0.8653 & $(0.0385)$ & -0.4407 & $(0.0481)$ \\
\hline Fishes & 0.8710 & $(0.0228)$ & 1.0388 & $(0.0243)$ & 0.3530 & $(0.0155)$ & -2.3920 & $(0.0209)$ & 0.1292 & $(0.0199)$ \\
\hline Powdered Milk & 0.8411 & $(0.0169)$ & 0.9462 & $(0.0187)$ & -0.0966 & $(0.0107)$ & 0.0661 & $(0.0110)$ & -1.7568 & $(0.0196)$ \\
\hline \multicolumn{11}{|l|}{ Pooled Urban-Rural } \\
\hline Eggs & -0.5004 & $(0.0034)$ & 0.2804 & $(0.0030)$ & 0.0438 & $(0.0015)$ & 0.0582 & $(0.0016)$ & 0.1180 & $(0.0021)$ \\
\hline Chicken Meat & 0.5996 & $(0.0067)$ & -1.1932 & $(0.0087)$ & 0.1098 & $(0.0033)$ & 0.1801 & $(0.0037)$ & 0.3037 & $(0.0050)$ \\
\hline Beef & 0.9829 & $(0.0316)$ & 1.0396 & $(0.0326)$ & -2.3511 & $(0.0372)$ & 0.5535 & $(0.0232)$ & -0.2250 & $(0.0289)$ \\
\hline Fishes & 0.6726 & $(0.0186)$ & 0.9677 & $(0.0197)$ & 0.3084 & $(0.0127)$ & -2.1181 & $(0.0172)$ & 0.1693 & $(0.0163)$ \\
\hline Powdered Milk & 0.7013 & $(0.0120)$ & 0.7850 & $(0.0134)$ & -0.0585 & $(0.0078)$ & 0.0795 & $(0.0080)$ & -1.5072 & $(0.0142)$ \\
\hline
\end{tabular}

Note: (...) standard error of mean.

Related to the total animal source food expenditure, chicken meat, beef, fish and milk are luxury goods, while (only) egg is normal goods. The luxuriousness of chicken meat, beef, fish and milk powder decrease with increasing household income level as expressed in quintile level. The consumers substitute high value commodities such as chicken meat, beef, fishes and powdered milk in case of rising prices with the cheaper and lower preferences. Consequently, households consume a less diversified diet in times of high animal source food prices, focusing their diet on cheaper animal source food commodities. High value animal source foods play an important role in a diversified and nutritionally balanced diet, since they are rich in proteins and essential amino acid. Animal source food "inflation", which has been led by high value animal agricultural commodities, therefore threatens to worsen the nutritional status of the Indonesian consumer, especially the lower income level.

\section{Conclusions and policy implications}

This study examined a complete demand system for Indonesia using data from the 2016 SUSENAS, with a set of demand parameter estimates for five major animal source food groups, by considering the size of household dan settlement type.
This article discussed how food prices impact animal food demand, by taking into account for changes in consumption patterns, i.e. substitution effects among food items, by including own and cross price elasticities obtained through the estimation of a demand system, QUAIDS. The estimation of QUAIDS and the respective results for income, compensated own and cross price elasticities show that high value animal food source commodities, such as chicken meat, beef, fish and milk powder are the most sensitive to its own price change, as well as to a change in income for eggs and chicken meat. All own price elasticities are negative and expenditure elasticities are positive for the entire sample as well as for income quintiles and for rural and urban sub-samples.

With respect to the total animal food expenditure, chicken meat, beef, fish and milk are luxury goods, while (only) egg is normal goods. The luxuriousness of chicken meat, beef, fish and milk powder decrease with increasing household income level as expressed in quintile level. Related to prices and expenditure, only egg is relatively price-inelastic and income-inelastic compared to the other animal source foods. The demand for animal source food in general tends to be "less" elastic at higher levels of income (from Q1 to Q5). The demand elasticities rural households are greater than urban households. 
Table 11. Uncompensated price elasticities across commodities by income quantile (source: author' computation from Susenas, 2016)

\begin{tabular}{|c|c|c|c|c|c|c|c|c|c|c|}
\hline \multirow{2}{*}{$\begin{array}{l}\text { Income } \\
\text { Quintile }\end{array}$} & \multicolumn{10}{|c|}{ Animal-source Foods } \\
\hline & \multicolumn{2}{|c|}{ Eggs } & \multicolumn{2}{|c|}{ Chicken Meat } & \multicolumn{2}{|c|}{ Beef } & \multicolumn{2}{|c|}{ Fishes } & \multicolumn{2}{|c|}{ Powdered Milk } \\
\hline $\begin{array}{l}\text { Q1. <20\% } \\
\text { (lowest) }\end{array}$ & \multicolumn{10}{|c|}{ Uncompensated Cross Elasticities (Marshallian) } \\
\hline Eggs & -0.9109 & $(0.0028)$ & 0.2257 & $(0.0027)$ & 0.0019 & $(0.0012)$ & 0.0368 & $(0.0013)$ & 0.0439 & $(0.0017)$ \\
\hline Chicken Meat & 0.0004 & $(0.0115)$ & -2.5402 & $(0.0155)$ & 0.2227 & $(0.0058)$ & 0.1083 & $(0.0064)$ & 0.2816 & $(0.0088)$ \\
\hline Beef & -2.6021 & $(0.1384)$ & 5.3002 & $(0.1550)$ & -7.4820 & $(0.1584)$ & 2.1791 & $(0.0988)$ & -2.0086 & $(0.1226)$ \\
\hline Fishes & -0.1560 & $(0.0341)$ & 0.6446 & $(0.0390)$ & 0.5210 & $(0.0225)$ & -3.1139 & $(0.0301)$ & 0.0386 & $(0.0286)$ \\
\hline $\begin{array}{l}\text { Powdered } \\
\text { Milk }\end{array}$ & -0.8052 & $(0.0222)$ & 0.6740 & $(0.0267)$ & -0.2125 & $(0.0138)$ & -0.0095 & $(0.0141)$ & -2.2046 & $(0.0250)$ \\
\hline \multicolumn{11}{|l|}{ Q2. 20-40\% } \\
\hline Eggs & -0.8687 & $(0.0029)$ & 0.1852 & $(0.0026)$ & 0.0133 & $(0.0012)$ & 0.0337 & $(0.0013)$ & 0.0519 & $(0.0018)$ \\
\hline Chicken Meat & -0.1267 & $(0.0084)$ & -1.9574 & $(0.0108)$ & 0.1388 & $(0.0042)$ & 0.1089 & $(0.0046)$ & 0.2201 & $(0.0064)$ \\
\hline Beef & -1.2783 & $(0.0950)$ & 2.7706 & $(0.0996)$ & -5.4536 & $(0.1105)$ & 1.4275 & $(0.0687)$ & -1.4936 & $(0.0858)$ \\
\hline Fishes & -0.2050 & $(0.0276)$ & 0.6742 & $(0.0295)$ & 0.4098 & $(0.0185)$ & -2.7375 & $(0.0248)$ & 0.0289 & $(0.0237)$ \\
\hline $\begin{array}{l}\text { Powdered } \\
\text { Milk }\end{array}$ & -0.6313 & $(0.0181)$ & 0.5172 & $(0.0205)$ & -0.1861 & $(0.0115)$ & -0.0146 & $(0.0117)$ & -2.0375 & $(0.0209)$ \\
\hline \multicolumn{11}{|l|}{ Q3. 40-60\% } \\
\hline Eggs & -0.8235 & $(0.0032)$ & 0.1488 & $(0.0028)$ & 0.0235 & $(0.0014)$ & 0.0315 & $(0.0015)$ & 0.0582 & $(0.0019)$ \\
\hline Chicken Meat & -0.1929 & $(0.0070)$ & -1.6443 & $(0.0089)$ & 0.0895 & $(0.0034)$ & 0.1085 & $(0.0037)$ & 0.1794 & $(0.0052)$ \\
\hline Beef & -0.6564 & $(0.0691)$ & 1.3593 & $(0.0695)$ & -4.1097 & $(0.0798)$ & 0.9766 & $(0.0497)$ & -1.0250 & $(0.0621)$ \\
\hline Fishes & -0.2311 & $(0.0237)$ & 0.6749 & $(0.0244)$ & 0.3358 & $(0.0158)$ & -2.4811 & $(0.0213)$ & 0.0222 & $(0.0202)$ \\
\hline $\begin{array}{l}\text { Powdered } \\
\text { Milk }\end{array}$ & -0.5189 & $(0.0152)$ & 0.3832 & $(0.0165)$ & -0.1477 & $(0.0096)$ & -0.0175 & $(0.0098)$ & -1.8709 & $(0.0175)$ \\
\hline \multicolumn{11}{|l|}{ Q4. 60-80\% } \\
\hline Eggs & -0.7524 & $(0.0039)$ & 0.1083 & $(0.0035)$ & 0.0395 & $(0.0017)$ & 0.0307 & $(0.0018)$ & 0.0718 & $(0.0023)$ \\
\hline Chicken Meat & -0.2392 & $(0.0061)$ & -1.3910 & $(0.0077)$ & 0.0472 & $(0.0029)$ & 0.1055 & $(0.0032)$ & 0.1401 & $(0.0044)$ \\
\hline Beef & -0.1743 & $(0.0348)$ & 0.2888 & $(0.0352)$ & -2.4605 & $(0.0395)$ & 0.4558 & $(0.0247)$ & -0.4568 & $(0.0307)$ \\
\hline Fishes & -0.2077 & $(0.0173)$ & 0.5529 & $(0.0178)$ & 0.2309 & $(0.0113)$ & -2.0527 & $(0.0153)$ & 0.0180 & $(0.0145)$ \\
\hline $\begin{array}{l}\text { Powdered } \\
\text { Milk }\end{array}$ & -0.3889 & $(0.0119)$ & 0.2402 & $(0.0127)$ & -0.1034 & $(0.0075)$ & -0.0167 & $(0.0077)$ & -1.6699 & $(0.0136)$ \\
\hline \multicolumn{11}{|l|}{$\begin{array}{l}5 .>80 \% \\
\text { (highest) }\end{array}$} \\
\hline Eggs & -0.6277 & $(0.0054)$ & 0.0431 & $(0.0053)$ & 0.0704 & $(0.0023)$ & 0.0302 & $(0.0025)$ & 0.1012 & $(0.0032)$ \\
\hline Chicken Meat & -0.3143 & $(0.0065)$ & -1.2001 & $(0.0086)$ & 0.0124 & $(0.0031)$ & 0.1178 & $(0.0034)$ & 0.1207 & $(0.0044)$ \\
\hline Beef & 0.0140 & $(0.0139)$ & -0.0765 & $(0.0151)$ & -1.5231 & $(0.0153)$ & 0.1616 & $(0.0096)$ & -0.1542 & $(0.0118)$ \\
\hline Fishes & -0.1850 & $(0.0132)$ & 0.4658 & $(0.0145)$ & 0.1630 & $(0.0085)$ & -1.7720 & $(0.0113)$ & 0.0148 & $(0.0107)$ \\
\hline $\begin{array}{l}\text { Powdered } \\
\text { Milk }\end{array}$ & -0.2290 & $(0.0080)$ & 0.1016 & $(0.0088)$ & -0.0590 & $(0.0049)$ & -0.0139 & $(0.0050)$ & -1.4350 & $(0.0089)$ \\
\hline
\end{tabular}

Note: (...) standard error of mean. 
Table 12. Compensated price elasticities across commodities by income quantile (source: author' computation from Susenas, 2016)

\begin{tabular}{|c|c|c|c|c|c|c|c|c|c|c|}
\hline \multirow{2}{*}{ Income Quintile } & \multicolumn{10}{|c|}{ Animal-source Foods } \\
\hline & \multicolumn{2}{|c|}{ Eggs } & \multicolumn{2}{|c|}{ Chicken Meat } & \multicolumn{2}{|c|}{ Beef } & \multicolumn{2}{|c|}{ Fishes } & \multicolumn{2}{|c|}{ Powdered Milk } \\
\hline $\begin{array}{l}\text { Q1. }<20 \% \\
\text { (lowest) }\end{array}$ & \multicolumn{10}{|c|}{ Compensated Cross Elasticities (Hicksian) } \\
\hline Eggs & -0.4634 & $(0.0028)$ & 0.3262 & $(0.0026)$ & 0.0057 & $(0.0012)$ & 0.0535 & $(0.0013)$ & 0.0779 & $(0.0017)$ \\
\hline Chicken Meat & 1.4316 & $(0.0118)$ & -2.2186 & $(0.0154)$ & 0.2349 & $(0.0058)$ & 0.1618 & $(0.0064)$ & 0.3903 & $(0.0088)$ \\
\hline Beef & 0.8239 & $(0.1411)$ & 6.0702 & $(0.1533)$ & -7.4528 & $(0.1584)$ & 2.3071 & $(0.0987)$ & -1.7483 & $(0.1226)$ \\
\hline Fishes & 1.3780 & $(0.0349)$ & 0.9894 & $(0.0385)$ & 0.5341 & $(0.0225)$ & -3.0566 & $(0.0301)$ & 0.1552 & $(0.0286)$ \\
\hline Powdered Milk & 1.0942 & $(0.0226)$ & 1.1009 & $(0.0263)$ & -0.1963 & $(0.0138)$ & 0.0615 & $(0.0141)$ & -2.0603 & $(0.0250)$ \\
\hline \multicolumn{11}{|l|}{ Q2. 20-40\% } \\
\hline Eggs & -0.4749 & $(0.0029)$ & 0.3117 & $(0.0026)$ & 0.0185 & $(0.0012)$ & 0.0533 & $(0.0013)$ & 0.0913 & $(0.0018)$ \\
\hline Chicken Meat & 0.9620 & $(0.0081)$ & -1.6076 & $(0.0108)$ & 0.1534 & $(0.0042)$ & 0.1630 & $(0.0046)$ & 0.3292 & $(0.0064)$ \\
\hline Beef & 1.4345 & $(0.0932)$ & 3.6422 & $(0.0996)$ & -5.4174 & $(0.1105)$ & 1.5623 & $(0.0687)$ & -1.2216 & $(0.0859)$ \\
\hline Fishes & 1.0275 & $(0.0270)$ & 1.0701 & $(0.0295)$ & 0.4262 & $(0.0185)$ & -2.6763 & $(0.0248)$ & 0.1525 & $(0.0237)$ \\
\hline Powdered Milk & 0.9532 & $(0.0177)$ & 1.0262 & $(0.0205)$ & -0.1650 & $(0.0115)$ & 0.0641 & $(0.0117)$ & -1.8786 & $(0.0209)$ \\
\hline \multicolumn{11}{|l|}{ Q3. 40-60\% } \\
\hline Eggs & -0.4796 & $(0.0031)$ & 0.2925 & $(0.0028)$ & 0.0305 & $(0.0014)$ & 0.0534 & $(0.0015)$ & 0.1032 & $(0.0019)$ \\
\hline Chicken Meat & 0.7012 & $(0.0068)$ & -1.2705 & $(0.0089)$ & 0.1076 & $(0.0034)$ & 0.1654 & $(0.0037)$ & 0.2964 & $(0.0052)$ \\
\hline Beef & 1.4598 & $(0.0674)$ & 2.2440 & $(0.0700)$ & -4.0669 & $(0.0798)$ & 1.1113 & $(0.0497)$ & -0.7483 & $(0.0621)$ \\
\hline Fishes & 0.7974 & $(0.0230)$ & 1.1049 & $(0.0245)$ & 0.3566 & $(0.0158)$ & -2.4156 & $(0.0213)$ & 0.1568 & $(0.0202)$ \\
\hline Powdered Milk & 0.8113 & $(0.0147)$ & 0.9393 & $(0.0166)$ & -0.1208 & $(0.0096)$ & 0.0672 & $(0.0098)$ & -1.6970 & $(0.0175)$ \\
\hline \multicolumn{11}{|l|}{ Q4. 60-80\% } \\
\hline Eggs & -0.4933 & $(0.0039)$ & 0.2598 & $(0.0035)$ & 0.0521 & $(0.0017)$ & 0.0580 & $(0.0018)$ & 0.1234 & $(0.0023)$ \\
\hline Chicken Meat & 0.4510 & $(0.0060)$ & -0.9875 & $(0.0078)$ & 0.0807 & $(0.0029)$ & 0.1783 & $(0.0032)$ & 0.2775 & $(0.0044)$ \\
\hline Beef & 1.0368 & $(0.0342)$ & 0.9968 & $(0.0353)$ & -2.4017 & $(0.0395)$ & 0.5837 & $(0.0246)$ & -0.2156 & $(0.0307)$ \\
\hline Fishes & 0.5450 & $(0.0169)$ & 0.9929 & $(0.0178)$ & 0.2675 & $(0.0113)$ & -1.9733 & $(0.0152)$ & 0.1679 & $(0.0144)$ \\
\hline Powdered Milk & 0.6116 & $(0.0116)$ & 0.8250 & $(0.0128)$ & -0.0548 & $(0.0075)$ & 0.0889 & $(0.0076)$ & -1.4707 & $(0.0136)$ \\
\hline \multicolumn{11}{|l|}{$\begin{array}{l}5 .>80 \% \\
\text { (highest) }\end{array}$} \\
\hline Eggs & -0.4772 & $(0.0055)$ & 0.1621 & $(0.0052)$ & 0.0954 & $(0.0024)$ & 0.0584 & $(0.0025)$ & 0.1614 & $(0.0032)$ \\
\hline Chicken Meat & 0.1824 & $(0.0066)$ & -0.8075 & $(0.0085)$ & 0.0950 & $(0.0031)$ & 0.2109 & $(0.0034)$ & 0.3192 & $(0.0044)$ \\
\hline Beef & 0.6343 & $(0.0140)$ & 0.4140 & $(0.0149)$ & -1.4199 & $(0.0153)$ & 0.2779 & $(0.0096)$ & 0.0937 & $(0.0118)$ \\
\hline Fishes & 0.3312 & $(0.0133)$ & 0.8740 & $(0.0143)$ & 0.2489 & $(0.0085)$ & -1.6752 & $(0.0113)$ & 0.2211 & $(0.0107)$ \\
\hline Powdered Milk & 0.4138 & $(0.0079)$ & 0.6099 & $(0.0087)$ & 0.0480 & $(0.0049)$ & 0.1066 & $(0.0050)$ & -1.1782 & $(0.0089)$ \\
\hline
\end{tabular}

Note: (...) standard error of mean. 
In a case of increasing animal source food prices, consumers substitute high value food items for cheaper alternatives. Consequently, households consume a less diversified diet in times of high animal source food prices, focusing their diet on cheaper animal source food commodities. High value animal source foods play an important role in a diversified and nutritionally balanced diet, since they are rich in proteins and essential amino acid. Animal source food "inflation", which has been led by high value animal agricultural commodities, therefore threatens to worsen the nutritional status of the Indonesian consumer, especially the lower income level.

\section{Acknowledgements}

This research was funded by the Ministry of Research, Technology \& Higher Education through Doctoral Dissertation Research Grant, for 2018 (No. 212/B.07/U.V/ LPPM/ 2018). This research was an output from the first authors' dissertation in the Doctoral Program in Agricultural Sciences at Brawijaya University, Malang, Indonesia. The authors wish to thank National Bureau of Statistics that provided statistical data required in this research. Authors are thankful to all statistical team who favor the authors in analyzing data.

\section{References}

Ackah, C., \& Appleton, S. (2007). Food price changes and consumer welfare in Ghana in the 1990s. CREDIT Research Paper.

Abbritti, M., Dell'Erba, M. S., Moreno, M. A., \& Sola, M. S. (2013). Global factors in the term structure of interest rates (No. 13-223). International Monetary Fund. https://doi.org/10.5089/9781475513516.001

Akaichi, F., \& Revoredo-Giha, C. (2014). The demand for dairy products in Malawi. African Journal of Agricultural and Resource Economics, 9(3), 214-225.

Banks, J., Blundell, R., \& Lewbel, A. (1997). Quadratic Engel curves and consumer demand. Review of Economics and statistics, 79(4), 527-539. https://doi.org/10.1162/003465397557015

Bellemare, M. F., Barrett, C. B., \& Just, D. R. (2013). The welfare impacts of commodity price volatility: evidence from rural Ethiopia. American Journal of Agricultural Economics, 95(4), 877-899. https://doi.org/10.1093/ajae/aat018

Bett, H. K., Musyoka, M. P., Peters, K. J., \& Bokelmann, W. (2012). Demand for meat in the rural and urban areas of Kenya: A focus on the indigenous chicken. Economics Research International, 2012, 1-10. https://doi.org/10.1155/2012/401472

Cockx, L., Rancken, N., \& Peiters, H. (2015). Food and nutrition security in the European Union: Overview and case studies, (March), 133.

Deaton, A., \& Muellbauer. J. (1980). Economics and consumer behavior. Cambridge University Press. https://doi.org/10.1017/CBO9780511805653
Elijah Obayelu, A., Okoruwa, V. O., \& Ajani, O. I. Y. (2009). Cross-sectional analysis of food demand in the North Central, Nigeria: The quadratic almost ideal demand system (QUAIDS) approach. China Agricultural Economic Review, 1(2), 173-193. https://doi.org/10.1108/17561370910927426

Indonesian Bureau of Statistics/Badan Pusat Statistik (BPS). (2016a). Pengeluaran Untuk Konsumsi Penduduk Indonesia Per Provinsi. Jakarta.

Indonesian Bureau of Statistics/Badan Pusat Statistik (BPS). (2016b). Survei Sosial Ekonomi Nasional. Jakarta.

Kadir, N. A. (2015). Menelusuri Akar Masalah Rendahnya Persentase Pemberian ASI Eksklusif di Indonesia. Jurnal alHikmah, 15(1), 114-125.

Karima, K., \& Achadi, E. L. (2012). Status gizi ibu dan berat badan lahir bayi. Kesmas: National Public Health Journal, 7(3), 111-119. https://doi.org/10.21109/kesmas.v7i3.57

Korir, L., Rizov, M., \& Ruto, E. (2018, April 16-18). Analysis of household food demand and its implications on food security in Kenya: an application of QUAIDS model. In 92nd Annual Conference. Warwick University, Coventry, UK. Agricultural Economics Society.

Mittal, S. (2010). Application of the QUAIDS model to the food sector in India. Journal of Quantitative Economics, 8(1), 4254.

Nendissa, D., \& Anindita, R., Hanani, N., \& Muhaimin, A. W. (2018). Beef market integration in East Nusa Tenggara of Indonesia. Russian Journal of Agricultural and Socio-Economic Sciences, 80, 380-387. https://doi.org/10.18551/rjoas.2018-08.51

Pangaribowo, E., \& Tsegai, D. (2011). Food demand analysis of Indonesian households with particular attention to the poorest. ZEF-Discussion Papers on Development Policy, (151), $1-38$.

https://www.econstor.eu/bitstream/10419/ 98222/1/770495125. pdf

Poi, B. P. (2012). Easy demand-system estimation with quaids. The Stata Journal, 12(3), 433-446. https://doi.org/10.1177/1536867X1201200306

Robert, K. W., Parris, T. M., \& Leiserowitz, A. A. (2005). What is sustainable development? Goals, indicators, values, and practice. Environment: Science and Policy for Sustainable Development, 47(3), 8-21. https://doi.org/10.1080/00139157.2005.10524444

Sa’diyah, A. A., Anindita, R., Hanani, N., \& Muhaimin, A. W. (2019). The strategic food demand for non poor rural households in Indonesia. EurAsian Journal of BioSciences, 13(2), 2197-2202.

Son, H. H., \& Kakwani, N. (2009). Measuring the impact of price changes on poverty. The Journal of Economic Inequality, 7(4), 395. https://doi.org/10.1007/s10888-008-9093-0

Survei Sosial Ekonomi Nasional (SUSENAS). (2016). Jakarta.

Tefera, N., Demeke, M., \& Rashid, S. (2012). Welfare impacts of rising food prices in rural Ethiopia: a quadratic almost ideal demand system approach NigussieTefera IFPRI. Research Gate. 